\title{
Some recommendations for an accurate estimation of Lanice conchilega density based on tube counts
}

\author{
Gert Van Hoey $\cdot$ Magda Vincx $\cdot$ Steven Degraer
}

Received: 28 October 2005/Revised: 10 April 2006/ Accepted: 11 April 2006/ Published online: 9 May 2006

(C) Springer-Verlag and AWI 2006

\begin{abstract}
The tube building polychaete Lanice conchilega is a common and ecologically important species in intertidal and shallow subtidal sands. It builds a characteristic tube with ragged fringes and can retract rapidly into its tube to depths of more than $20 \mathrm{~cm}$. Therefore, it is very difficult to sample L. conchilega individuals, especially with a Van Veen grab. Consequently, many studies have used tube counts as estimates of real densities. This study reports on some aspects to be considered when using tube counts as a density estimate of $L$. conchilega, based on intertidal and subtidal samples. Due to its accuracy and independence of sampling depth, the tube method is considered the prime method to estimate the density of L. conchilega. However, caution is needed when analyzing samples with fragile young individuals and samples from areas where temporary physical disturbance is likely to occur.
\end{abstract}

Keywords Lanice conchilega · Tube counts · Belgian Continental Shelf

\section{Introduction}

The tube building polychaete Lanice conchilega (Pallas 1766) is a dominant species of European intertidal and

Communicated by H.-D. Franke

G. Van Hoey $(\bowtie) \cdot$ M. Vincx $\cdot$ S. Degraer

Marine Biology Section, Department of Biology,

Ghent University, Krijgslaan 281/S8,

9000 Ghent, Belgium

e-mail: g.vanhoey@UGent.be shallow subtidal sands (Ropert 1996; Van Hoey et al. 2004). The species is of high ecological importance since (1) its dense populations affect sediment properties (Jones and Jago 1993) and oxygen transport (Forster and Graf 1995), (2) it alters the composition of benthic communities (Zühlke 2001), and (3) it is an important food item for birds and fish (Petersen and Exo 1999). The worms build very characteristic tubes, made of cemented sand grains and shell breccia (Ziegelmeier 1952). The top of the tube usually projects a few centimeters above the sediment and carries a ragged fringe. Lanice conchilega itself can grow up to a length of $30 \mathrm{~cm}$, while its tube can reach a length of $65 \mathrm{~cm}$ (Ziegelmeier 1952). When disturbed, the worm can rapidly retract into its tube to depths of more than $20 \mathrm{~cm}$ (Ziegelmeier 1952; Dales 1955). Consequently, it is very difficult to sample L. conchilega individuals with corers for intertidal sampling (Heuers et al. 1998; Petersen and Exo 1999; Ropert and Dauvin 2000; Strasser and Pieloth 2001; Zühlke 2001; Callaway 2003) and certainly with a Hamon grab (Ropert and Dauvin 2000) or a Van Veen grab in the case of subtidal populations (Buhr and Winter 1977; this study). Generally, a Van Veen grab (50-70 kg, not loaded with extra weight), frequently used in macrobenthic studies, penetrates $10-15 \mathrm{~cm}$ into the sediment, depending on the type of substrate (Beukema 1974). When using this sampling device, an underestimation of the real density by specimen counts could thus be expected.

Observations in the field and in fixed samples, however, indicated that unoccupied tubes are different from tubes occupied by $L$. conchilega, which can be discerned by the existence of a certain rigidity of the tube, caused by cement mucus produced by L. conchilega. Observations also suggested that the 
tube top with the fringe is destroyed shortly after the worm had died or abandoned the tube, although remains of tubes can still be found in the sediment until several months later (Zühlke 2001). Therefore, many studies use the number of tubes with a well developed ragged fringe and certain rigidity, as a direct reflection of the abundance of L. conchilega (Ropert and Dauvin 2000; Strasser and Pieloth 2001; Zühlke 2001; Callaway 2003).

This paper reports on some aspects to be considered when using tube counts as an estimate of Lanice conchilega density.

\section{Methods}

Three subtidal sampling stations (O1, WK2 and WK1) with high local abundance of $L$. conchilega were selected for this study, in the coastal zone of the Belgian Continental Shelf (BCS). All three stations were sampled monthly (September-April) or biweekly (May-August) during the period March 2002-September 2003 (23 sampling dates). The macrobenthic samples were taken with a Van Veen grab $\left(0.1026 \mathrm{~m}^{2}\right)$ on board of the research vessel 'Zeeleeuw'. The samples were fixed in $8 \%$ formaldehyde-seawater and sieved over a $1 \mathrm{~mm}$ and $0.5 \mathrm{~mm}$ sieve. The samples were treated with care in order to avoid destruction of the L. conchilega tubes.

The volume of the sediment was recorded to estimate the sampling depth of the Van Veen grab for each sample. The grain size distribution of a sub sample from the Van Veen was determined with a LS Coulter particle size analyzer: median grain size of the fraction $2-850 \mu \mathrm{m}$ and mud content (volume percentage with particles $<64 \mu \mathrm{m}$ ) were used as granulometric variables.

A field study at the Flemish beach nature reserve "Baai van Heist" (Belgium) was set up to test the relationship between tube counts and number of L. conchilega individuals as a function of excavated depth. Cores $\left(0.0031 \mathrm{~m}^{2}\right)$ were inserted into the sand down to different depths $(5,10,15,20$ and $30 \mathrm{~cm})$. Three replicate samples were collected per depth and sieved over a $1 \mathrm{~mm}$ sieve.

In this study the L. conchilega individuals (further referred to as specimen counts) as well as the tubes with a well developed ragged fringe (further referred to as tube counts) were counted in the samples. These two methods can be used to estimate the real density of this polychaete at a certain place and time. Valid tube counts were based on the following criteria, irrespective of tube length: (1) tubes have a well developed ragged fringe at the end, (2) they have a good rigidity, and (3) they are not filled with sand.

The non-parametric Mann-Whitney $U$ test and median or Kruskal-Wallis test was used to test for significant differences between tube and specimen counts at different depths, and Spearman rank was used to trace correlations between variables.

\section{Results}

Field study

By digging out sampling cores down to different depths, a sampling-depth dependent relationship between tube and specimen counts was found (Fig. 1). At a depth of $5 \mathrm{~cm}$, on average $82 \%$ less specimens than valid tubes were found (Mann-Whitney $U$ test: $P=0.049)$. At a depth of $10 \mathrm{~cm}(9 \%$ less specimens than valid tubes), no significant differences between the two counting methods was found (Mann-Whitney $U$ test: $P=0.83$ ). From $15 \mathrm{~cm}$ depth onwards, equal values for the two counting methods were found [Mann-Whitney $U$ test: $P=0.66(15-20 \mathrm{~cm})$ and $P=1$ $(30 \mathrm{~cm})$ ], indicating a good estimate of the real density of $L$. conchilega. Counts of tubes with fringes were not dependent of depth (Median test: $P=0.8925)$, whereas specimen counts were (Median test: $P=0.0469$ ).

Abiotic variables

The median grain size of most of the samples varied between 150 and $250 \mu \mathrm{m}$, whereas the mud content varied mostly between 0 and $20 \%$ (muddy, fine sandy sediment) (Fig. 2). There was no correlation between sampled volume and median grain size (Spearman rank: $P=0.9$ ), whereas a positive, though low correlation was found between sampled volume and mud content (Spearman rank: $P=0.036$ ).

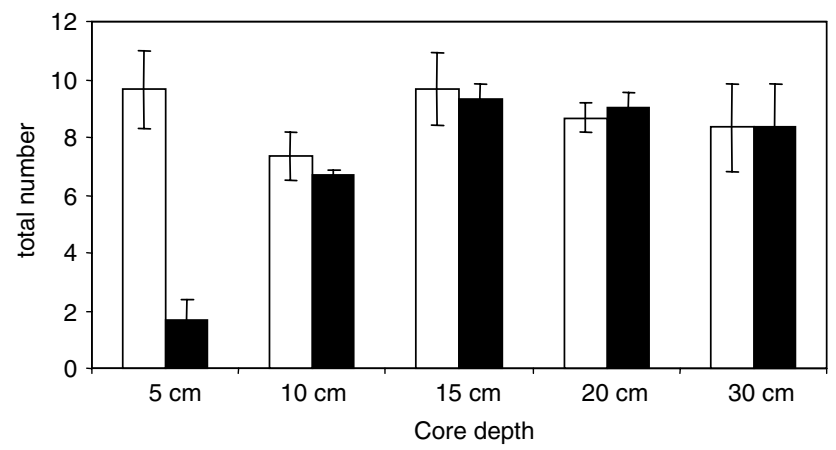

Fig. 1 Tube counts (white columns) and specimen counts (black columns) at different sampling depths, with indication of the standard error taken in the field 


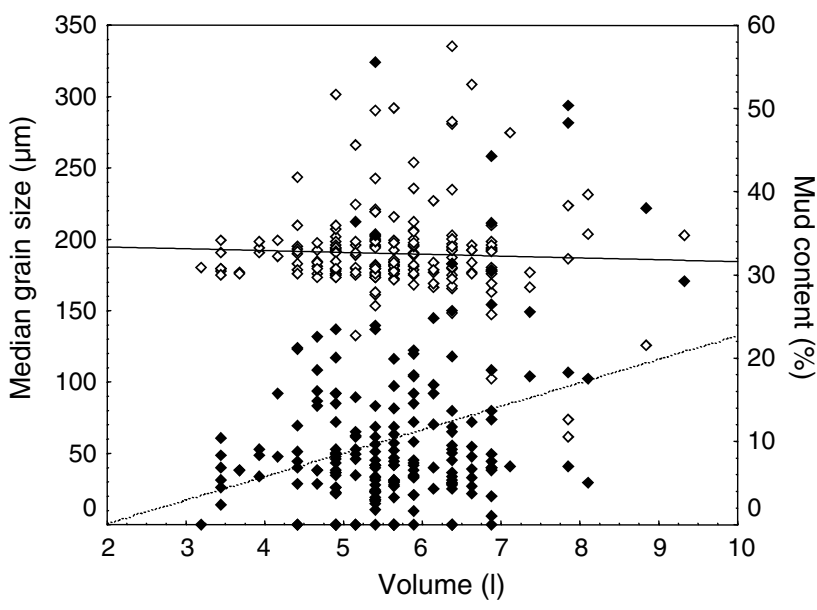

Fig. 2 Median grain size $(\mu \mathrm{m})$ (open rhombus, black trend line) and mud content (\%) (black rhombus, dotted trend line) against sample volume (liter), with indication of a trend line

The sampled volume ranged between 3.19 and 9.331 , and the variance between the different sampling stations was low (average volume of $5.97 \pm 1.11$ (SD) for station O1, $5.51 \pm 0.931$ for station WK2, $5.4 \pm 0.921$ for station WK1). The maximum volume of a Van Veen grab was about 15.051 at the maximal sampling depth of $18.5 \mathrm{~cm}$. The volume range obtained for the three stations is in accordance with a sampling depth of the Van Veen grab varying between 5.5 (3.03 l) and $12 \mathrm{~cm}(9.23 \mathrm{l})$.

Valid tube counts versus specimen counts

More tubes than specimens were counted at most sampling occasions for the three separated stations (Fig. 3). However, no correlation was found between the percentage differences between tube and specimen counts and the sampled volume (Spearman rank: $P=0.24$ ) (Fig. 4a). On a few sampling occasions there were more specimens than fringed tube counts. These sampling occasions were characterized by the absence of tubes with well developed fringes or by high densities of small tubes (spring-summer). A significant difference was found between the percentage differences between tube and specimen counts and the season of sampling (Kruskal-Wallis test: $P=0.0121$ ). Most occasions where tube counts were lower than specimen counts were in spring and summer (Fig. 4b).

\section{Discussion}

The intertidal field study at the beach of Heist showed that counting fringed tubes is a good method for estimating Lanice conchilega density. This is mainly
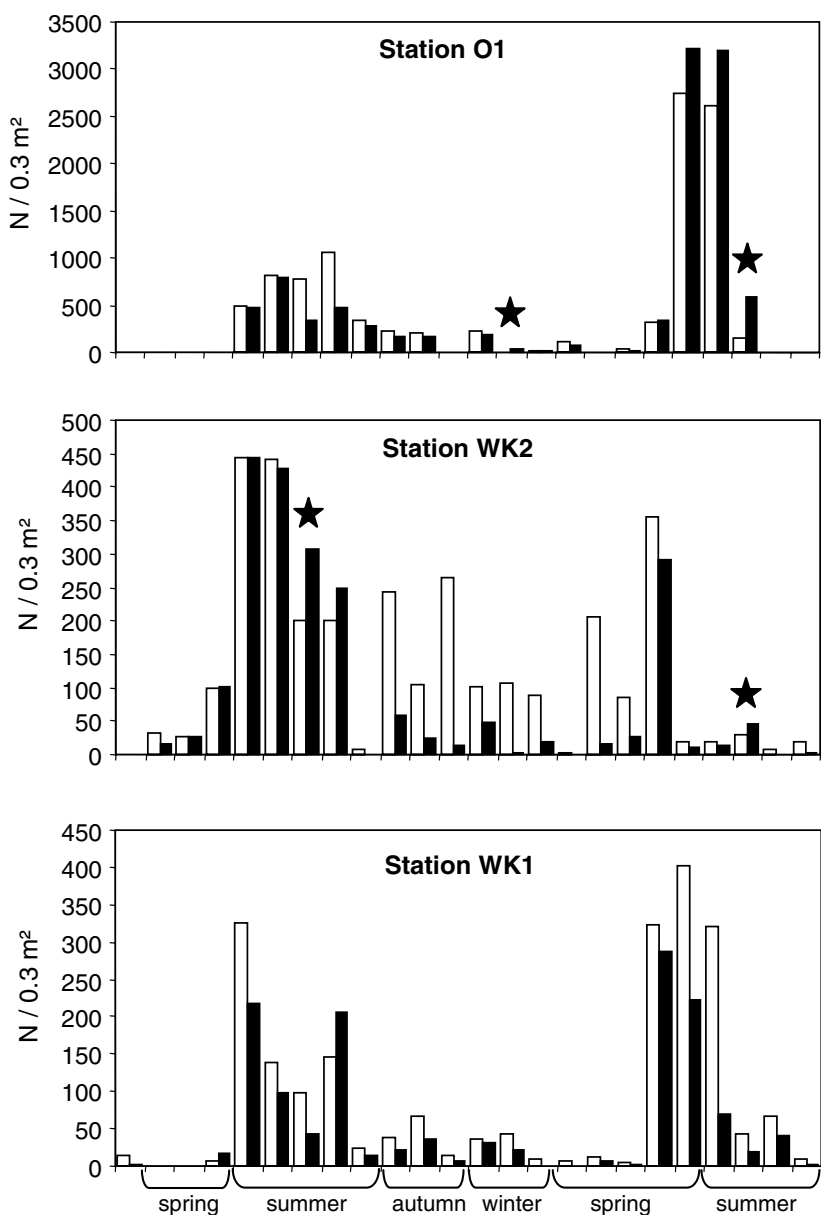

Fig. 3 Differences between tube counts (white column) and specimen counts (black columns), expressed in ind $/ 0.3 \mathrm{~m}^{2}$. The star indicates samples with absence of tubes with well developed fringes

due to the sediment-depth independency of the method, which is not the case for specimen counts. However, not every sampling method reaches adequate depths of at least $10 \mathrm{~cm}$. In the case of sampling with a Van Veen grab, a strong underestimation of the real density is given by counts of larger worms, such as $L$. conchilega, due to the low sampling efficiency (Beukema 1974). Sampling efficiency is only high for species that live in the upper five centimeters of the bottom (Ursin 1956; Lie and Pamatmat 1965; Beukema 1974). Additionally, the average sediment content of a Van Veen depends on the coarseness of the sediment: the grab penetrates relatively deep in both very fine (sand with a high proportion of mud) and very coarse sand, whereas relatively small volumes were obtained from fine sands that had low proportions or no mud at all (Beukema 1974). In our study the sedimentology of the three stations was characterized by fine sands with a varying mud 

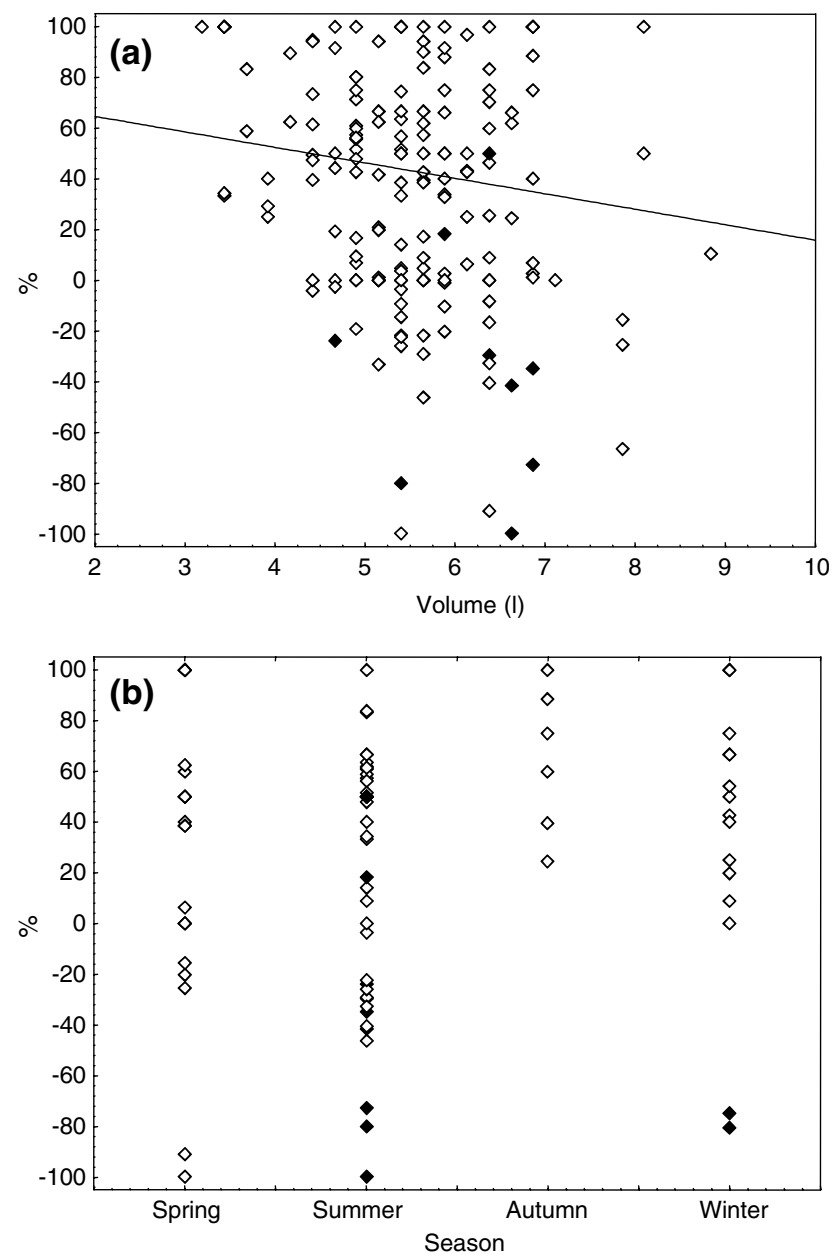

Fig. 4 a Scatter plot of sample volume against the percentage differences between tube and specimen counts ( $\mathrm{N}$ (tube) $-\mathrm{N}$ $($ specimen $) / \mathrm{N}(\max ) \times 100)$. Black rhombus indicates samples lacking tubes with well developed fringes. b Scatter plot of the season against the percentage differences between tube and specimen counts. Black rhombus indicates samples lacking tubes with well developed fringes

content $(0-20 \%$ or more), and the sampled volume increased with increasing mud content. The average sampled volume at the three stations corresponded with a Van Veen grab penetration depth of 5-12 cm. Although a Van Veen grab, under ideal sampling conditions, makes a horizontal rather than a semicircular cut on a sandy substrate (Lie and Pamatmat 1965), personal observations showed that a semi-circular cut is not unusual at our sampling sites. Due to this characteristic shape of the Van Veen grab, L. conchilega tubes at the outside of the grab are sampled less efficiently, even when the Van Veen reaches its maximal sampling depth $(18.5 \mathrm{~cm})$. Therefore, it is advisable to use the tube tops with fringes, irrespective of tube length, as an estimate of L. conchilega density, as was already done in previous studies (Ropert and Dauvin 2000; Strasser and Pieloth 2001; Zühlke 2001; Callaway 2003).

Strasser and Pieloth (2001) also found a strong linear correlation (Spearman rank $r=0.97, P<0.001$ ) between the number of tube top counts and living worms, although the tube counts slightly overestimated the number of animals present (trend line above the 1:1 ratio). This supports the idea that the shape of the tubes (U- or W-type) is independent of density (Strasser and Pieloth 2001). Therefore, the authors proposed a correction factor of 0.73 to estimate real densities. However, in the case of high L. conchilega densities, this correction is too strong, whereas for low densities patches the correction factor is too weak. That is why a correction factor should be replaced by a regression equation depending on the L. conchilega abundance. Furthermore, since both methods in our field study rendered exactly the same density estimates at a sampling depth of $30 \mathrm{~cm}$ (Mann-Whitney $U$ test: $P=1.000)$, it can be expected that this number reflects the real density of $L$. conchilega. This conclusion confirms the one to one relationship between the number of fringed tubes and the real density of L. conchilega, at least in high density patches such as the ones at the beach of Heist. The one to one relationship in high density patches also supports the idea that the shape of L. conchilega tubes is indeed density dependent (no U- or W-shaped tubes).

Higher numbers of tubes compared to specimens were found on most occasions, as expected based on the sampling efficiency of a Van Veen grab. However, sometimes lower numbers of tubes than specimens were recorded. Two hypotheses might explain these deviations from the general pattern. Firstly, in some cases this may be mainly due to the absence of tubes with well developed fringes. The destruction of the tube fringe could be caused by previous disturbances, like beam-trawl fishery (sampling areas are characterized by a high beam-trawl frequency; personal observations) or even storm conditions (not the case on the discussed sampling dates). Lanice conchilega normally rebuilds its tube very quickly (within $48 \mathrm{~h}$ ), but the form of the fringes of the tubes can differ according to the water condition (Nicolaidou 2003). In still water the fringe of the new tube was thinner and extended to all directions, while under a wave regime the individual branches were thicker and positioned perpendicularly to the direction of the waves. Secondly, tube tops of young adults (tube diameter 1.0$1.5 \mathrm{~mm}$ ) are more fragile and less developed (personal observations) and therefore more sensitive to destruction during sieving or sorting. This factor may explain the lower number of tubes during periods with 
high abundances of young individuals (i.e., springsummer).

Acknowledgements The first author acknowledges a grant from the Institute for the Promotion of Innovation through Science and Technology in Flanders (IWT, Flemish Government). The authors would like to thank everybody who assisted in collecting and analyzing the macrobenthos samples (about the whole Marine Biology Section), the sedimentological samples (e.g., Danielle Schram) and who made improvements to earlier drafts (Sofie Vandendriessche). I also want to thank the crew of the research vessel 'Zeeleeuw' for their assistance during the sampling campaigns and the institute AMINAL (Flemish administration responsible for environment, nature, land and water management, department Nature) for the permission to collect samples in the beach nature reserve "Baai van Heist".

\section{References}

Beukema JJ (1974) The efficiency of the Van Veen grab compared with the Reineck box sampler. J Cons Int Explor Mer 35:319-327

Buhr KJ, Winter JE (1977) Distribution and maintenance of a Lanice conchilega association in the Weser estuary (FRG), with special reference to the suspension-feeding behaviour of Lanice conchilega. In: Keegan BF, Ceidigh PO, Boaden PJS (eds) Biology of benthic organisms. 11th European symposium on marine biology, Gallaway, Oct. 1976. Pergamon Press, Oxford and New York, pp 101-113

Callaway (2003) Juveniles stick to adults: recruitment of the tube-dwelling polychaete Lanice conchilega (Pallas, 1766). Hydrobiolgia 503: 121-130

Dales RP (1955) Feeding and digestion in terebellid polychaetes. J Mar Biol Ass UK 34:55-79

Forster S, Graf G (1995) Impact of irrigation on oxygen flux into the sediment: intermittend pumping by Callianassa subterraneai and 'piston-pumping' by Lanice conchilega. Mar Biol 123:335-346
Heuers J, Jaklin S, Zühlke R, Dittmann S, Günther C-P, Hildenbrandt H, Grimm V (1998) A model on the distribution and abundance of the tube-building polychaete Lanice conchilega (Pallas, 1766) in the intertidal of the Wadden Sea. Verhandl Ges Okol 28:207-215

Jones SE, Jago CF (1993) In situ assessment of modification of sediment properties by burrowing invertebrates. Mar Biol 115:133-142

Lie U, Pamatmat MM (1965) Digging characteristics and sampling efficiency of the $0.1 \mathrm{~m}^{2}$ Van Veen grab. Limnol Oceanogr 10:379-384

Nicolaidou A (2003) Observations on the re-establishment and tube construction by adults of the polychaete Lanice conchilega. J Mar Biol Ass UK 83:1223-1224

Petersen B, Exo K-M (1999) Predation of waders and gulls on Lanice conchilega tidal flats in the Wadden Sea. Mar Ecol Prog Ser 178:229-240

Ropert M (1996) Particularités du recrutement et du renouvellement d'une population de Lanice conchilega (Polychaeta, Terebellidae) associée a la conchyliculture en Baie Des Veys (Baie De Seine Occidentale). J Rech Océanogr 21:118-125

Ropert M, Dauvin J-C (2000) Renewal and accumulation of a Lanice conchilega (Pallas) population in the Baie des Veys, western Bay of Seine. Oceanol Acta 23:529-546

Strasser, Pieloth (2001) Recolonization pattern of the polychaete Lanice conchilega on an intertidal sand flat following the severe winter of 1995/96. Helgol Mar Res 55:176-181

Ursin E (1956) Efficiency of marine bottom sampler of the Van Veen and Petersen types. Meddr. Danm. Fisk - og Havunders, N.S 1(7):1-8

Van Hoey G, Degraer S, Vincx M (2004) Macrobenthic community structure of soft-bottom sediments at the Belgian Continental Shelf. Estuar Coast Shelf S 59:599-613

Ziegelmeier E (1952) Beobachtungen über den Röhrenbau von Lanice conchilega (Pallas) im Experiment und am natürlichen Standort. Helgoländer wiss Meeresunters 4:107-129

Zühlke R (2001) Polychaete tubes create ephemeral community patterns: Lanice conchilega (Pallas, 1766) associations studied over six years. J Sea Res 46:261-272 